Saudi Journal of Business and Management Studies Abbreviated Key Title: Saudi J Bus Manag Stud ISSN 2415-6663 (Print) IISSN 2415-6671 (Online) Scholars Middle East Publishers, Dubai, United Arab Emirates Journal homepage: https://saudijournals.com/sibms

Review Article

\title{
Perspective of Financial Literacy on Agribusiness Performance in Uganda; A Close Look at Farmers' Attitude and Social Media Platforms
}

\author{
Mutya Tomasi* \\ Kumi University Kumi Town, Uganda
}

DOI: $10.36348 /$ sjbms.2020.v05i01.010

| Received: 04.01.2020 | Accepted: 11.01.2020 | Published: 24.01.2020

*Corresponding author: Mutya Tomasi

\section{Abstract}

Given the increasing importance of agribusiness in the world's emerging economy, the dissemination of financial literacy information is necessary to content and sustain commercial production. Financial literacy is being a coded a great contributor to financial stability and sustainable economic development. Studies have showed that financial literacy affects the level of agribusiness performance. However, these studies have failed to incorporate the moderating role of farmers' attitude and social media in the relationship between financial literacy and agribusiness performance. The results indicate that farmers' attitude and social media practices positively and significantly moderates in the relationship between financial literacy and agribusiness performance in a $21^{\text {st }}$ century.

Keywords: financial literacy, Agribusiness, farmers' attitude, social media, performance.

Copyright @ 2020: This is an open-access article distributed under the terms of the Creative Commons Attribution license which permits unrestricted use, distribution, and reproduction in any medium for non-commercial use (NonCommercial, or CC-BY-NC) provided the original author and source are credited.

\section{INTRODUCTION}

The world population at seven billion currently, is expected to reach nine billion by 2050 and may exceed ten billion by the end of the century, posing a challenge to future production. The growing population will culminate into increased demand for agricultural products such as meat, pork, cereals and vegetables; necessitating agribusiness practitioners to make calculated financial decisions. Inadequate financial information is still a hard to reach problem [1], the Findex data present 2 million adults unbanked in 2014 with a slight decline to 1.7 million in 2017 indicating approximately $40 \%$ of the world. Majority farmers lack sufficient information, knowledge and skills on financial concepts and instruments to make informed financial decisions [2]. Extant findings reveal many individuals across the world being financially illiterate.

Financial literacy provides confidence and flexibility to saving products and loans. The drastic increment in financial literacy not only prevents negative impact on financial markets but also seals corporate governance gap. According to Qin Fan Vania
B. Salas Garcia [3], financially skilled farmers search the market effectively and efficiently, demonstrate power to kick out producers in a dishonest and incompetent business state. Compelling financial literacy is a decisive factor, of which; farmers can proactively determine availability and accessibility to financial services [4]. For example, when young adults (ages 18-24) in the United States of America were asked the high-school level course that most benefited their lives, more than 50\% responded in favor of "money management". Georgia, Idaho, and Texas mandated financial education; after three years of implemention, all the three observed increment in credit scores and lower delinquency rates within credit accounts [5]. Thus, constructive individual and institutional research has emphasized need for financial literacy to a code culture status across businesses [6]. The governments and international development organizations must build institutional formal financial capacity [7], articulate financial literacy as a strong predictor of individual demand for financial services. In this regard, farmers need financial literacy in order to address complex financial situations. Therefore financial decisions of firms require up to date knowledge and skills in financial literacy (Grohmann, 
Mutya Tomasi; Saudi J Bus Manag Stud, Jan., 2020; 5(1): 74-83

Kouwenberg and Menkhoff [1]; current managers, who attend financial literacy programs, obtain knowledge and skills to enhance revenue generation at a minimal cost (Pierre-Carl Michaud [8].

A gap in literature exists in respect to attitude and social media platforms as potential to capitalize on in today's digital environment. The strength of this deficiency is observed in the current substantial changes in the financial technological environment. The challenge encountered is failure to address farmers' perception and social media as a whole and formulation of unique models, theories and methodology to necessitate farms predict, learn, appreciate and adapt them in the agribusiness sector. Thus the researcher presents new financial literacy design with an understanding of farmers' perception and social media platforms in a technological environment for prioritization. The researcher observes that social media in businesses has gained attention as low-cost and highexposure information sharing strategy; the daily use of social-media is driven by the network effect and the managers' attitudes [9]. In Uganda, social media has a sound coverage; face book $82.6 \%$, whatsApp $89.0 \%$, twitter $10.1 \%$, linkedlin $16.5 \%$, YouTube $19.3 \%$, blogs $18.3 \%$ and $0.8 \%$ google+ among phone users [10]. The recent slowdown of Uganda's economy is a result of poor financial literacy in the agricultural sector [11]. We notice only 16 percent of the population keep their savings at formal deposit taking institutions, 60 percent still keep their savings at home in form of assets such as animals, and more than 65 percent are unable to access formal financial institutions for credit.

Current research studies [3, 9] have observed financial literacy as a pillar to consistent performance over time. Therefore, this paper antecedents on financial literacy literature and examines the moderating role of perception and social media platforms and what the agriculture sector will encounter in order to propose a new research direction. The researcher proposes knowledge spillover theory to build on creation of new and quick financial information channels to enhance financial inclusion among farmers. Findings indicate that farmers' attitude and social media platforms usage need to be informed by farmers need and interest not mere digital development. A conceptual model is provided to direct the future research studies. This study therefore assumes;

H1. Financial literacy will have a direct positive effect on agribusiness performance.

H2. Farmers' attitude will have a positive moderating effect on the relationship between financial literacy and agribusiness performance.

H3. Social media will have a positive moderating effect on the relationship between financial literacy and agribusiness performance.

\section{Review of related literature}

In this section we review the existing literature on financial literacy by looking at what scholars have suggested on its importance and arguments on enhancing performance. We take into account the critics on financial literacy: the perception nature of business people in the era of social media. The research work intends to underscore the fact that "clear desire to perpetually remain ignorant on social media platforms" is in itself a form of rigid perception. This is an area that has rarely been explored and which the research paper intends to contribute to the existing literature in the agricultural sector.

\section{Knowledge spill over theory}

In this theory, the creation of new knowledge expands the set of technological opportunity. This necessitates modern online social media platforms like Face book, YouTube, and Twitter which the study is to explore. We observe that knowledge spillover entails exchange of ideas which can upholds farmers to a positive perception regarding financial literacy. This accelerates the rate of financial information dissemination among farmers in Uganda with huge social media coverage. The theory focuses on individual agents with endowments of new economic knowledge as the unit of analysis in a model of economic growth, rather exogenously assumed firms. Agents with new knowledge endogenously pursue the exploitation of financial knowledge since knowledge spill over comes from the stock of knowledge thus the need for agribusinesses to appreciate research and development to promote entrepreneurship According to Çinla Akdere and Pelin Benli [12], Schumpeter's analysis of entrepreneurial innovation, which takes place in the real economy, also proposes a theoretical account for understanding the dynamics of financial innovations. The number of firms located close to a business is positively influenced by the knowledge capacity of that sector like agriculture and the knowledge output of the universities. Thus, there is considerable evidence suggesting that the Knowledge Spillover theory of Entrepreneurship holds for agribusiness farmers as well as for other industries. According to Elif Akben Selcuk [13], the basic argument is that knowledge created endogenously through research and development results into knowledge spillovers. Thus such spillovers can give rise to opportunities for appreciating financial information for health agribusiness performance.

\section{Financial literacy}

According to Deleze and Korkeamaki [14], financial literacy is defined as having the knowledge, skills and confidence to manage one's own finances well, tracking into account of one's economic and social circumstances. In this context, "knowledge" is the ability to understand personal and broader financial matters, "skill" is the ability to apply that knowledge in everyday life and "attitude" is the ability to have confidence and make sound financial decisions. Thus 
Mutya Tomasi; Saudi J Bus Manag Stud, Jan., 2020; 5(1): 74-83

financial literacy is the act of being able to effectively make informed decisions regarding the use and management of finances by individuals or groups. This can enable people to budget well their finances, participate in savings, look on for better interest rates for debt and ensure that there is proper record keeping. The practice of financial discipline enables people to understand better their cash inflows and outflows. Chen, Jiajun and $\mathrm{Yu}$ [6], expounds that financial literacy needs to become part of every business culture so as to enhance performance. Organizations should create a sense of continued practice for stake holders to understand the value for money and respect accountability. According to Grohmann, Kouwenberg and Menkhoff [1], financial literacy involves "being able to make informed judgments to take effective decisions regarding the use and management of money. The decisions need to be tailored towards heavy savings in the budgeted activities, acquiring spending on interest from activity based debt and employing qualified financial personnel to ensure proper book keeping. This leaves financial literacy as a key factor in financial training [6], and requires that it should be a routine exercise.

Summary of literature on financial literacy and its effect on agribusinesses

\begin{tabular}{|c|c|c|c|c|}
\hline Author (s) & Year & Observation & $\begin{array}{l}\text { Moderating } \\
\text { variable }\end{array}$ & $\begin{array}{l}\text { Evidence } \\
\text { area }\end{array}$ \\
\hline $\begin{array}{l}\text { Délèze Frédéric and } \\
\text { Korkeamäki Timo, }\end{array}$ & 2018 & $\begin{array}{l}\text { Firms need financial literacy to ensure } \\
\text { effective management in their interest rate } \\
\text { risk with new debts issue. }\end{array}$ & Stock markets & Europe \\
\hline $\begin{array}{l}\text { Babych Yaroslava, } \\
\text { Grigolia Maya and } \\
\text { Keshelava, Davit }\end{array}$ & 2018 & $\begin{array}{l}\text { Current government policy initiatives and } \\
\text { strategy documents aimed at improving } \\
\text { financial access of SMEs and household } \\
\text { needs to be reviewed for efficiency and } \\
\text { effectiveness. }\end{array}$ & Financial education & USA \\
\hline $\begin{array}{l}\text { Antonia Grohmann, Roy } \\
\text { Kouwenberg and Lukas } \\
\text { Menkhoff }\end{array}$ & 2018 & $\begin{array}{l}\text { Family and school work positively affects } \\
\text { the financial literacy of adults. }\end{array}$ & Participation & Germany \\
\hline $\begin{array}{l}\text { Neha Garg \& Shveta } \\
\text { Singh }\end{array}$ & 2018 & $\begin{array}{l}\text { Financial literacy among youths can help } \\
\text { in making policy interventions }\end{array}$ & $\begin{array}{l}\text { Socio-economic and } \\
\text { emographic factors }\end{array}$ & India \\
\hline $\begin{array}{l}\text { Sayili Koray, Yilmaz, } \\
\text { Gokhan, Dyer, Douglas } \\
\text { and Küllü, A. Melih, }\end{array}$ & 2017 & $\begin{array}{l}\text { The effect of institutional investors } \\
\text { depends on the firm relative level of } \\
\text { financial literacy to enhance innovation } \\
\text { through research and development. }\end{array}$ & $\begin{array}{l}\text { Creativity and } \\
\text { invention }\end{array}$ & Canada \\
\hline Pierre-Carl Michaud & 2017 & $\begin{array}{l}\text { Financial literacy leads to more effective } \\
\text { savings for retirement and better debt } \\
\text { management. }\end{array}$ & $\begin{array}{l}\text { Financial } \\
\text { information }\end{array}$ & $\begin{array}{l}\text { Canada } \\
\text { and USA }\end{array}$ \\
\hline $\begin{array}{l}\text { Shen Chung-Hua, Lin } \\
\text { Shih-Jie, Tang De-Piao } \\
\text { and Hsiao Yu-Jen }\end{array}$ & 2016 & $\begin{array}{l}\text { People with high financial literacy are } \\
\text { less likely to experience financial } \\
\text { disputes. They can handle their purchase } \\
\text { or sale transactions with minimal or no } \\
\text { financial dispute. }\end{array}$ & $\begin{array}{l}\text { Personal } \\
\text { characteristics }\end{array}$ & Taiwan \\
\hline $\begin{array}{l}\text { Ćumurović, Aida and } \\
\text { Hyll, Walter }\end{array}$ & 2016 & $\begin{array}{l}\text { Financial literacy positively affects the } \\
\text { probability of being self employed. As } \\
\text { financial literacy is acquired, } \\
\text { entrepreneurial activities increase. }\end{array}$ & Economic education & Germany \\
\hline $\begin{array}{l}\text { Németh, Katalin Jakovác, } \\
\text { Aranka Mészáros, Péter } \\
\text { Kollár and Viktor } \\
\text { Várpalotai }\end{array}$ & 2016 & $\begin{array}{l}\text { Assessment and development of financial } \\
\text { literacy programs must be done in an } \\
\text { organized, transparent and in a quality } \\
\text { controlled way. }\end{array}$ & Training & Hungary \\
\hline $\begin{array}{l}\text { Calcagno Riccardo and } \\
\text { Monticone Chiara, }\end{array}$ & 2015 & $\begin{array}{l}\text { Investors with low levels of financial } \\
\text { literacy are less likely to consult an } \\
\text { adviser. }\end{array}$ & $\begin{array}{l}\text { Strategic } \\
\text { interactions }\end{array}$ & $\begin{array}{l}\text { Netherland } \\
\text { s }\end{array}$ \\
\hline Elif Akben Selcuk & 2014 & $\begin{array}{l}\text { Appreciation of financial knowledge, } \\
\text { financial attitude and financial behavior } \\
\text { as major dimensions. }\end{array}$ & $\begin{array}{l}\text { Financial knowledge } \\
\text { and attitudes }\end{array}$ & Turkey \\
\hline $\begin{array}{l}\text { Sokoya Albiola Abosede, } \\
\text { Adefunke Olanike Alabi } \\
\text { and Faybola Bolaule } \\
\text { Oluyemis } 2014\end{array}$ & 2014 & $\begin{array}{l}\text { Financial information and awareness } \\
\text { programs in agricultural practice are key } \\
\text { for food security nation's all-round } \\
\text { wealth. }\end{array}$ & Awareness & Nigeria \\
\hline
\end{tabular}


Mutya Tomasi; Saudi J Bus Manag Stud, Jan., 2020; 5(1): 74-83

According to Grohmann, Kouwenberg and Menkhoff [1], financial literacy involves "being able to make informed judgments to take effective decisions regarding the use and management of money. The decisions need to be tailored towards heavy savings in the budgeted activities, with spending on interest from activity based debt and employing qualified financial personnel to ensure proper book keeping [6].

\section{Savings}

According to Cillero, Thorne, Wallace, Breen, Hennessy [15], illustrates financial literacy as the mastery set of knowledge, attributes and behaviors that has assumed a fundamental role in allowing and enabling people to make responsible decisions regarding savings so as to attain financial wellbeing. According to Shelley, Marianne, Aryyeetey and Marquis [16], farmers today with micro savings have retained their great knowledge of interest rates, increased levels of savings making them able to manage their wellbeing. This therefore, implies that even religious bodies should inculcate financial literacy teaching in their program to accommodate different business owners to address their needs. This therefore will make owners of SMEs in the agribusiness practice to treat financial literacy as a culture to enhance their performance [17]. Savings can offer great meaning if it's done in groups, and having trained members to provide leadership for good scheme performance. This supports the government of Uganda introduction of SACCOs to have people learn and deal with their finances in a grouped manner. Therefore, financial education efforts translate into greater financial literacy which is a relative determinant of financial decision making which can uphold the saving culture among agribusiness practitioners in their respective groups [18].

In the study of Clark Shelley, Paul Mariane, Aryyeetey Richmond and Marquis Grace [16], savings have enhanced investment and agricultural performance as a result of sharing financial literacy information. This is because agribusiness investment is very instrumental in rural areas for development, not only directly by alleviating poverty but also indirectly increase agricultural productivity and employment. Therefore both government and private investments are very essential for economic transformation as a result of disseminated financial literacy information to the entire population. Declan French, Donal McKillop [19], illustrated that financial education makes more agribusiness practioners to advance in technology which promotes efficiency and effectiveness in operation management. This was based on the "business model"; in this model, financial products are designed to serve the continent's unbanked populations. It targets low income markets to achieve scale through high volume of relatively small low margin transactions. However, Yang, Ishtiaq and Anwar [20], stretches that firms are not receiving adequate financial education which is a component of financial inclusion and bank account usage is not taken emphasis of. This therefore calls for the readiness of farmers to receive the financial education and ensure that it's taken care of; as well attitude, demand and commitment are important for financial literacy to yield fruits. According to Smith and Stein [21], adaptation and usage of savings products and services can be hindered by poor transaction costs, lack of trust and regulatory barriers, information and knowledge gaps, social constraints and behavior bias. They also emphasized the need to "save for tomorrow" model, this implies reduced external assistance, improved members empowerment through trainings, education and engagement of agricultural economics students and youth in cooperatives. For example access to affordable financial services is a significant challenge in Africa, where the majority of the population is excluded from financial banking sector. In 2007, more than 70 percent of households in Kenya relied on informal sources of financing. The inaccessibility to formal financial services negatively impacts livelihoods in Uganda by increasing transaction costs and risks, limited market exchange and limiting opportunities for households to save. Therefore according to Okello, Ntayi, Munene and Nabeta [5], the absence of effective social capital financing in Uganda, financial literacy mail fails to enhance the level of financial inclusion among rural households. Thus the need for all economic planning to be future based signifying that food security matters are sustainable for every community leading to self-reliance.

\section{Debt management}

According to Deleze and Korkeamaki [22], Households need to underestimate the real cost of loans and not understate the value of outstanding debt. They emphasize in their findings that financially illiterate households have low net worth as they use high cost credit and report credit arrears or difficulty in paying their debts. On the other hand, financially literate households often co-hold liquid savings and resolve consumer credit, thus there is need for co-holding through rational financial behavior this can uphold performance in the agricultural sector. However, according to Patrick M. Emerson and Bruce McGough [23], debt knowledge can be associated with sector, occupations, level of management and level of education. It is ascertained that individuals with low levels of debt literacy tend to transact in high cost manners, incurring higher fees and using high cost borrowing, they also report that their debt loads are excessive or they are unable to judge their debt position. Therefore, this can be attributed to ignorance which can be addressed with financial information relating to debt management across communities so as to have a clear borrowing culture which will enhance agricultural development in different economies of the world. Most business managers have a fair knowledge of debt management and majority do not understand the effect of inflation and interest rates on loans they borrow (as) 
Mutya Tomasi; Saudi J Bus Manag Stud, Jan., 2020; 5(1): 74-83

they don't compare terms and conditions before purchasing financial products [18]. She further ascertained that even though people appreciate the need to operate bank accounts for their businesses, majority do not effectively utilize existing bank services. She also supported that there is need to incorporate financial education in school curriculum from primary level so that individuals are financially informed early in life.

\section{Record keeping}

Historically, many agribusiness farmers have found record keeping and analyzing financial records as a challenge [1]. However, financial record keeping helps business owners to know their savings status and enables developing groups to know the amount each debtor owed. There is a number of manual system and computer record keeping systems available today to necessitate quality performance in agribusiness practice. The manual system is the cheapest and easiest way of recording financial transactions in a journal format of purchases and sales activities when they occur. The entries should show date, the item involved, quantity and the cash involved in purchase or sale. The use of computerized software has expanded on agribusiness operations in recent years. It's faster, accurate and powerful in analysis. According to Qin Fan Vania B. Salas Garcia [3], advances in technological system for record keeping have allowed agricultural products and agribusinesses to acquire large amounts of production data more efficiently. These advantages have also refined the concept of agribusiness management towards a more detailed precise site specific level. Informations stipulated that, there is no clear empirical economic evidence associated to high agribusiness profitability.

According to Alhassan Musah and Muazu Ibrahim [24], the owners of agribusinesses are very reluctant when it comes to recording their daily activities such as revenue and expenditure. Most of them do not even take the initiative to keep the primary cash book as they entirely rely on mental records about the costs, revenue and debt. However, most of them feel compelled to maintain records when their agribusinesses are improving. There record keep could also be contingent on how businesses perform. To the contrary, Qin Fan Vania B. Salas Garcia [3] argues that most small and medium businesses do not keep records due to lack of accounting knowledge and the feared costs of hiring professional accountants. As a result, there is insufficient use of accounting information to support financial performance in agribusinesses which makes it difficult for entrepreneurs to calculate their profits clearly. Upon such a background, failure to keep records is associated to lack of financial knowledge and skills among managers despite of some few having the willingness to learn. Accurate financial and production records will always help farmers analyze performance of farm operations and make necessary adjustments to run the business more efficiently which increases productivity and profitability.

Planning, monitoring, controlling, coordination and evaluation play a vital role and have a positive effect on agribusiness performances. Therefore financial information on budgeting is important for annual reviews as a permanent practice. This helps in planning for future operations, refine existing strategic plans and consider how they can respond to current competitions Alhassan Musah and Muazu Ibrahim [24]. The budgetary process should also consider both firm needs and parameters within the firm during planning to achieve better results. Thus, budgets should always be implemented as planned and management and should pay great attention on all the budgeting processes since it improves firm performance. This indicates that budgets are viewed as imperative instruments in arranging and controlling assts to upgrade execution in numerous organizations Qin Fan Vania B. Salas Garcia [3]. Therefore for any business to remain relevant in today's technological competitive environment there is need for managers to consistently strengthen the budgeting system in all departments so as to enhance business performance.

\section{Farmers' attitude}

Farmers' attitude has a shopping influence on purchase perception [21]. Flow, on the other hand, does have an influence on shopping intention and purchase behavior. With a positive approach, farmers can feel in control and confident and they will perform at their best, whereas a negative approach will damage confidence, harm performance, paralyze the mental skills and may also impact on health [25]. Business owners running successful small and medium sized businesses have a range of attitudes and behaviours that contribute to the success of their businesses. Financial literacy requires agribusiness farmers to know what they want to achieve in order to fulfill their dream in today's competitive economy. Therefore, managers need to have enough financial education including employee representatives from different departments to create a whole financial effect in the organisation [4]. Managers need to understand the attitude of the organization and look to hire people that are a good fit. They need to create a template for the attitude needed. To do this, they should look at the top performers and see the kind of attitude they possess and analyze the soft skills that make them successful.

\section{Social media}

Literature has found that the decline in productivity has been due to technological regress and low growth in technical efficiency and scale efficiency. Policy options aimed at improving agricultural productivity and output growth will require strengthening of extension services; improving the financial management skills of farmers through training; and by encouraging farmers to adopt and 
Mutya Tomasi; Saudi J Bus Manag Stud, Jan., 2020; 5(1): 74-83

utilize technologies that have been provided under existing policy programs [25]. Majority of the people today spend valuable time doing business on their online systems; good number check update information on their phones regularly using the social media platforms. Those with social media access are more likely to sell on the foreign market than those without social media access. Internet access tends to have larger impacts on volume decisions. In addition to direct effects, we find that social media access has significant and positive spillover effects on market participation and volume decisions in the global market. Findings provide empirical support for policies and social programs that promote information computer technology especially internet usage in Uganda to improve smallholder farmers' marketing performance [9]. We notice E-commerce and e-business has gained attention as a relatively low-cost and high-exposure marketing strategy. The findings indicate social-media business practices being largely driven by the network effect and the managers' attitudes. According to Qin Fan Vania B. Salas Garcia [3], small and medium enterprises need to appreciate the social media platform to expand their market share.

\section{Study model}

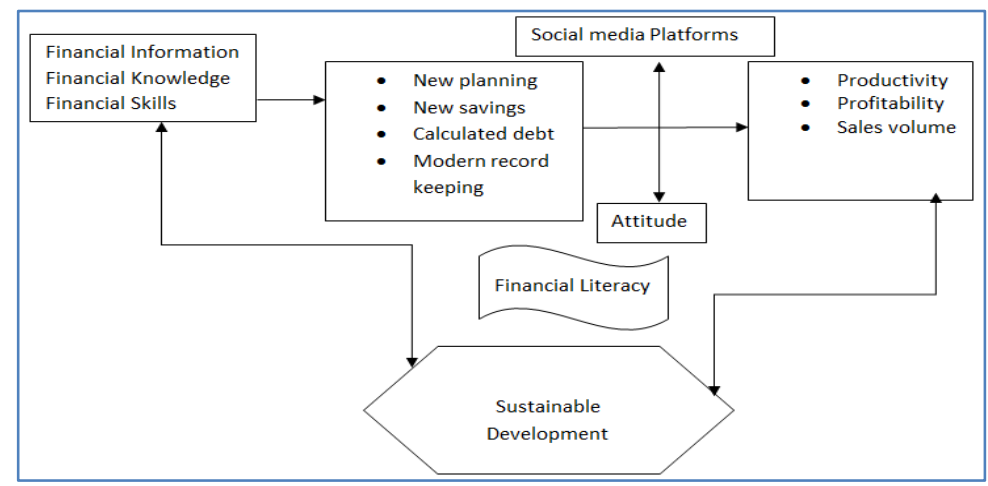

Considering a competitive market environment where agribusiness has to be boasted to meet the increased demand, efficient and effective financial literacy will be necessary. Financial information, knowledge and skills will offer new approaches to budgeting, savings and record keeping; this will be moderated with individual or group perceptions and the $21^{\text {st }}$ quick, easy and low price technological social platforms such as face book, whatsApp and twitter information channels to farmers to necessitate high productivity, profits, and increased sales volume. The model presents sustainable development as the most significant output of applied financial information and skills by financial literate farmers. This model presents financial literacy as a process designed towards sustainable economic development for an increasingly technological environment.

\section{METHODOLOGY}

The study employed a cross sectional design where the previous work in line or related to financial literacy and agribusiness performance were central. Materials were obtained from reports, and journals. Farmers in the area of study responded to the moderating role of farmers' attitude and social media in the relationship between financial literacy and agribusiness performance. The self-administered questionnaires were given to respondents. The ideas in the context of budgeting, savings, debt management and record keeping were explored as parameters of financial literacy, farmers' attitude and social media usage which agribusiness practitioners need to embrace so as to attain efficient and effective operations in the agricultural sector. The data was coded and organized and analysis using SPSS to determine the mean and standard deviation of the variables.

\section{Measures of Financial literacy}

Evaluative legitimacy of financial literacy is consistent with our legitimate approach; we illustrate the relative legitimacy by different national and global scholars or researchers on financial literacy. The researcher seeks farmers' response on the understanding of financial literacy, their perception on financial literacy products and services, the channels used by different institutions in disseminating financial information. These helped to determine the basic knowledge on financial literacy among agribusiness practitioners [9]. In line with Nyupriya and Rekha [26], the researcher identified budgeting and savings policies in the ministry Debt knowledge being associated with sector, occupations, level of management and level of financial education [13], and clear record keeping in accounting systems to support financial performance.

\section{Measures of Agribusiness performance}

The researcher effectively evaluated agribusiness performance on the basis of productivity, sales volume, profitability and sustainable development among communities in Uganda. Farmers were examined as to whether they understand their cost and revenue per month, the volume of goods and services they offer, whether they arrive at profit and if they understand their market share. This enables us to 
Mutya Tomasi; Saudi J Bus Manag Stud, Jan., 2020; 5(1): 74-83

determine their level of financial literacy in terms of output [16]. Many practitioners and academic scholars have emphasized the need for quality performance in the agribusiness sector as a bridge to rapid growing demands both locally and internationally [27]. The government of Uganda has come up with programs like NAADS to increase on production and commercialize the golden sector.

\section{Measures of farmers' attitude and social media}

Farmers' attitude is evaluated basing on their response to financial services. Farmers' examined on their perceived expectations from financial literacy and any other form of financial training; their willingness to attend financial literacy seminars, workshops, On the other hand, their understanding of information computer technology, mobile internet usage, and the social media impact in today's global environment; the forms of social media used, such as face book, twitter WhatApp and others with the associated costs. According to [9], new-media marketing has gained attention as a relatively low-cost and high-exposure marketing strategy. The findings reveal that the daily use of socialmedia marketing strategy is largely driven by the available network effect and the managers' attitudes.

\section{RESULTS}

Financial literacy Descriptive Statistics

\begin{tabular}{|l|r|r|r|r|r|}
\hline \multicolumn{7}{|c|}{ Descriptive Statistics } \\
\hline & $\mathrm{N}$ & Minimum & Maximum & Mean & Std. Deviation \\
\hline 1 & 47 & 1 & 5 & 3.19 & 1.424 \\
\hline 2 & 47 & 1 & 5 & 2.85 & 1.063 \\
\hline 3 & 47 & 1 & 5 & 3.66 & 1.356 \\
\hline 4 & 47 & 1 & 5 & 4.11 & .914 \\
\hline 5 & 47 & 1 & 5 & 3.83 & 1.185 \\
\hline 6 & 47 & 1 & 5 & 3.53 & 1.316 \\
\hline 7 & 47 & 1 & 5 & 3.57 & 1.229 \\
\hline 8 & 47 & 1 & 5 & 4.17 & .940 \\
\hline 9 & 47 & 1 & 5 & 3.91 & 1.039 \\
\hline 10 & 47 & 1 & 5 & 3.06 & 1.389 \\
\hline 11 & 47 & 1 & 5 & 3.49 & 1.159 \\
\hline Average & & & & $\mathbf{3 . 8 3}$ & $\mathbf{1 . 3 1 6}$ \\
\hline
\end{tabular}

Measuring financial literacy in an agribusiness sector may be an uphill task. Findings showed an average mean of 3.83 and standard deviation 1.316 implying that knowledge on financialmtters exhibits variations agribusiness production. We nail financial literacy to hold farmers to manage their agricultural systems well [3]. We observe financial literacy as not only mean to make a profit but equally minimising losses [13]. Farmers situations are at times delicate, what becomes critical is to make a rational decision at the right moment. "As a farmer you can sell your products at a loss so as to minimise losses." For one to do this it requires financial literacy. We present financial information and awareness programs in agricultural practice as fundamental for food security; it improves on cultivation, harvesting and storage that reduces famine and improves the nation's all-round wealth [13]. Thus positions financial literacy as a critical factor in improving the quality of life and enhancing financial inclusion in Uganda. Therefore, the effect of institutional investors depends on the firm relative level of financial literacy to enhance innovation through research and development Sayili, Yilmaz, Dyer, Melih, [28]. Investors with low levels of financial literacy are less likely to consult financial advisers; they delegate their portfolio choice more often or do not invest in any risky asset at all [29].

Section D: social media

Descriptive Statistics

\begin{tabular}{|l|r|r|r|r|r|}
\hline \multicolumn{7}{|c|}{ Descriptive Statistics } \\
\hline & $\mathrm{N}$ & Minimum & Maximum & Mean & Std. Deviation \\
\hline 1 & 47 & 1 & 5 & 2.45 & 1.230 \\
\hline 2 & 47 & 1 & 5 & 2.28 & 1.192 \\
\hline 3 & 47 & 1 & 5 & 2.66 & 1.273 \\
\hline 4 & 47 & 1 & 5 & 3.23 & 1.108 \\
\hline 5 & 47 & 1 & 5 & 2.81 & 1.154 \\
\hline 6 & 47 & 1 & 5 & 2.98 & 1.242 \\
\hline 7 & 47 & 1 & 5 & 2.72 & 1.192 \\
\hline 8 & 47 & 1 & 5 & 2.21 & 1.318 \\
\hline 9 & 47 & 1 & 5 & 2.74 & 1.326 \\
\hline Average & & & & $\mathbf{2 . 6 2}$ & $\mathbf{1 . 1 8 1}$ \\
\hline
\end{tabular}


Mutya Tomasi; Saudi J Bus Manag Stud, Jan., 2020; 5(1): 74-83

The average mean for the items on social media in the above table was found to be 2.62 and standard deviation of 1.232 , this implies that there is a moderating effect of social media in the relationship between financial literacy and agribusiness performance. The $21^{\text {st }}$ century is a world of technology [10]; knowledge sharing, creativity and innovation practices. This is in line with Schumpeter's spill over innovation theory which emphasizes knowledge created endogenously through research and development to result into knowledge spillovers [12]. Therefore, social media has taken over communication in the fastest form not expected. Majority of the farmers posses phones, can read and write, have access to internet. Majority of the farmers today check update information on their phones regularly using the social media platforms. Those with social media access are more likely to sell on the foreign market than those without social media access. Internet access tends to have larger impacts on volume decisions. In addition to direct effects, we find that social media access has significant and positive spillover effects on market participation and volume decisions in the global market. findings provide empirical support for policies and social programs that promote information computer technology especially internet usage in rural Peru to improve smallholder farmers' marketing performance [9]. New-media marketing has gained attention as a relatively low-cost and high-exposure marketing strategy. The findings reveal that the daily use of social-media marketing is largely driven by the network effect and the managers' attitudes. They also indicate that the small-sized firms receive higher returns from social media use in terms of increased sales [3].

Section C Farmers attitude

\begin{tabular}{|l|r|r|r|r|r|}
\hline \multicolumn{7}{|c|}{ Descriptive Statistics } \\
\hline & $\mathrm{N}$ & Minimum & Maximum & \multicolumn{1}{c|}{ Mean } & Std. Deviation \\
\hline 1 & 47 & 1 & 5 & 3.40 & 1.116 \\
\hline 2 & 47 & 1 & 5 & 3.55 & 1.059 \\
\hline 3 & 47 & 1 & 5 & 3.87 & .969 \\
\hline 4 & 47 & 1 & 5 & 3.40 & 1.035 \\
\hline 5 & 47 & 1 & 5 & 3.98 & 1.073 \\
\hline 6 & 47 & 1 & 5 & 3.74 & 1.293 \\
\hline 7 & 47 & 1 & 5 & 3.91 & 1.039 \\
\hline 8 & 47 & 2 & 5 & 4.23 & .865 \\
\hline Average & & & & $\mathbf{3 . 7 6}$ & $\mathbf{1 . 1 8 8 5}$ \\
\hline
\end{tabular}

The average mean for the items on farmers' attitude in the above table was found to be 3.76 and standard deviation of 1.1885 , this implies that there is a high moderating effect of social media in the relationship between financial literacy and agribusiness performance. According to our findings, farmers' attitude on financial literacy is determined by the ease to access financial information at a minimal or no cost level. This is backed by the knowledge spillover theory that presents the need for idea exchange to take advantage of the technological opportunities. Thus current government policy initiatives and strategy documents aimed at improving financial access of small and medium enterprises needs to be reviewed and tailored towards financial awareness in the agricultural sector [27]. We address the increasing misconception of financial advisors as alternatives for financial literacy as stated by the respondents. Famers need to possess a positive attitude on financial training programs [20], take advantage of the modern technology. This will lead to increase in productivity, sales volume, profitability and sustainable development in the agribusiness sector. It is the duty of educational institutions and agricultural departments to teach farmers what they need in financial awareness. Once, they know the "golden" value of the land and how to manage it, they will stick to it utilizing most of the potential that is present.

Agro business performance

\begin{tabular}{|l|r|r|r|r|r|}
\hline \multicolumn{7}{|c|}{ Descriptive Statistics } \\
\hline & $\mathrm{N}$ & Minimum & Maximum & \multicolumn{1}{c|}{ Mean } & Std. Deviation \\
\hline 1 & 47 & 1 & 5 & 4.51 & .930 \\
\hline 2 & 47 & 2 & 5 & 4.45 & .802 \\
\hline 3 & 47 & 2 & 5 & 4.51 & .688 \\
\hline 4 & 47 & 2 & 5 & 4.74 & .607 \\
\hline 5 & 47 & 1 & 5 & 3.85 & 1.063 \\
\hline 6 & 47 & 1 & 5 & 3.89 & .866 \\
\hline Average & & & & $\mathbf{4 . 2 3 2}$ & $\mathbf{. 8 4 2 1}$ \\
\hline
\end{tabular}


Mutya Tomasi; Saudi J Bus Manag Stud, Jan., 2020; 5(1): 74-83

The average mean for the items on agribusiness performance in the above table was found to be 4.232 and standard deviation of 0.8421 . Productivity, profitability, sales volume and high market share shall be achieved in a strong financial literacy environment. Many practitioners and academic scholars have emphasized the need for quality performance in the agribusiness sector as a bridge to rapid growing demands both locally and internationally [27]. The government of Uganda has come up with programs like NAADS to increase on production and commercialize the golden sector.

\section{CONCLUSION}

We appreciate the fact that financial literacy leads to rational decisions. However, to the best of our knowledge, this is the first research paper in the $21^{\text {st }}$ technological world that analyses the moderating role of farmers' attitude and the social media effect in the relationship between financial literacy and agribusiness performance. Our study presents farmers' positive perception on financial literacy as a green card to unlock financial information. In the global village today, social media communication has taken precedence as the cheapest and fastest channel to financial information sharing [27]. The findings reveal that the daily use of social-media platforms is largely driven by the network effect and the managers' attitudes. Therefore, this unique study contributes to the body of literature in the area of financial literacy by introducing new moderating variables.

In this study, the researcher suggests a quality strategy for policy makers to address farmers' perception on financial matters while incorporating the social platforms in unlocking potential among rural and urban farmers to make rational financial decisions. The researcher argues governments to invest more in technology and offer internet services as a public good; train more experts for quality financial education. Agribusiness farmers will then enhance interest and demand for financial literacy for knowledge and skills in areas of budgeting, savings, debt management and record keeping. The skills and knowledge in financial literacy enables them adapt modern technology such as usage of computerized systems to ease work in their groups which eventually smoothens production activities alongside agricultural value chain [9].

This study concentrated on views regarding the farmers with no attention to customers, which leaves a big gap in the study area. Therefore, there is need for future researchers to conduct an empirical study on moderating role of customers' attitude and social media in the relationship between financial literacy and agribusiness performance.

\section{REFERENCE}

1. Grohmann, A., Klühs, T., \& Menkhoff, L. (2018). Does financial literacy improve financial inclusion? Cross country evidence. World Development, 111, 84-96.

2. Agarwal, S., Amromin, G., Ben-David, I., Chomsisengphet, S., \& Evanoff, D. D. (2015). Financial literacy and financial planning: Evidence from India. Journal of Housing Economics, 27, 421.

3. Fan, Q., \& Salas Garcia, V. B. (2018). Information access and smallholder farmers' market participation in Peru. Journal of Agricultural Economics, 69(2), 476-494.

4. Calcagno, R., \& Monticone, C. (2015). Financial literacy and the demand for financial advice. Journal of Banking \& Finance, 50, 363380 .

5. Okello Candiya Bongomin, G., Ntayi, J. M., Munene, J. C., \& Nkote Nabeta, I. (2016). Social capital: mediator of financial literacy and financial inclusion in rural Uganda. Review of International Business and Strategy, 26(2), 291-312.

6. Chen, J., Jiang, J., \& Liu, Y. J. (2018). Financial literacy and gender difference in loan performance. Journal of Empirical Finance, 48, 307-320.

7. Skagerlund, K., Lind, T., Strömbäck, C., Tinghög, G., \& Västfjäll, D. (2018). Financial literacy and the role of numeracy-How individuals' attitude and affinity with numbers influence financial literacy. Journal of behavioral and experimental economics, 74, 18-25.

8. Lusardi, A., Michaud, P. C., \& Mitchell, O. S. (2017). Optimal financial knowledge and wealth inequality. Journal of Political Economy, 125(2), 431-477.

9. Yao, B., Shanoyan, A., Peterson, H. H., Boyer, C., $\&$ Baker, L. (2019). The use of new-media marketing in the green industry: Analysis of social media use and impact on sales. Agribusiness, 35(2), 281-297.

10. Cunningham, P. M., Cunningham, M., \& Ekenberg, L. (2014, December). Baseline analysis of 3 innovation ecosystems in East Africa. In 2014 14th International Conference on Advances in ICT for Emerging Regions (ICTer) (pp. 156-162). IEEE.

11. Harelimana, J. B. (2017). The Effect of Budgetary Control on Financial Performance of Kigali Serena hotel in Rwanda.

12. Akdere, Ç., \& Benli, P. (2018). The nature of financial innovation: a post-schumpeterian analysis. Journal of Economic Issues, 52(3), $717-$ 748.

13. Akben-Selcuk, E., \& Altiok-Yilmaz, A. (2014). Financial literacy among Turkish college students: The role of formal education, learning approaches, and parental teaching. Psychological reports, 115(2), 351-371.

14. Délèze, F., \& Korkeamäki, T. (2018). Interest rate risk management with debt issues: Evidence from Europe. Journal of Financial Stability, 36, 1-11. 
Mutya Tomasi; Saudi J Bus Manag Stud, Jan., 2020; 5(1): 74-83

15. Martinez Cillero, M., Thorne, F., Wallace, M., Breen, J., \& Hennessy, T. (2018). The Effects of Direct Payments on Technical Efficiency of Irish Beef Farms: A Stochastic Frontier Analysis. Journal of agricultural economics, 69(3), 669-687.

16. Clark, S., Paul, M., Aryeetey, R., \& Marquis, G. (2018). An assets-based approach to promoting girls' financial literacy, savings, and education. Journal of adolescence, 68, 94-104.

17. Agyei, S. K. (2018). Culture, financial literacy, and SME performance in Ghana. Cogent Economics \& Finance, 6(1), 1463813.

18. Brennan, M. J., \& Kraft, H. (2018). Leaning against the wind: Debt financing in the face of adversity. Financial Management, 47(3), 485-518.

19. French, D., \& McKillop, D. (2016). Financial literacy and over-indebtedness in low-income households. International Review of Financial Analysis, 48, 1-11.

20. Mutya, T., \& Josephine, A. (2018). Financial Management a Wheel to Financial Performance of Local Governments in Uganda: A Case Study of Tororo Municipal Council. J Bus Fin Aff, 7(330), 2167-0234.

21. Yang, K. C., Huang, C. H., Yang, C., \& Yang, S. Y. (2017). Consumer attitudes toward online video advertisement: YouTube as a platform. Kybernetes, 46(5), 840-853.

22. Délèze, F., \& Korkeamäki, T. (2018). Interest rate risk management with debt issues: Evidence from Europe. Journal of Financial Stability, 36, 1-11.
23. Emerson, P. M., \& McGough, B. (2018). Learning about education. Economic Inquiry, 56(1), 263 277.

24. Musah, A., \& Ibrahim, M. (2014). Record keeping and the bottom line: Exploring the relationship between record keeping and business performance among small and medium enterprises (SMEs) in the Tamale Metropolis of Ghana. Research Journal of Finance and Accounting, 5(2), 107117.

25. Temoso, O., Hadley, D., \& Villano, R. (2018). Sources of efficiency, productivity and output growth in Botswana agriculture. Review of Development Economics, 22(3), 1105-1124.

26. Ma, W., Grafton, R. Q., \& Renwick, A. (2018). Smartphone use and income growth in rural China: Empirical results and policy implications. Electronic Commerce Research, 124.

27. Berger, A. N. (2003). The economic effects of technological progress: Evidence from the banking industry. Journal of Money, credit and Banking, 141-176.

28. Sayili, K., Yilmaz, G., Dyer, D., \& Küllü, A. M. (2017). Style investing and firm innovation. Journal of Financial Stability, 32, 17 29.

29. Charlotta, B., Bino, C' s., Gustav, J. (2012). Situating financial literacy. Critical Perspectives on https://doi:10.1016/j.cpa.2012.11.011 